\title{
STATYSTYCZNY OBRAZ POLSKICH BIBLIOGRAFII SPECJALNYCH W LATACH 1945-2008
}

\author{
Jadwiga Sadowska \\ Instytut Informacji Naukowej \\ i Bibliotekoznawstwa \\ Uniwersytetu Wrocławskiego
}

Bibliografia Bibliografii Polskich 1945-2008, bibliografia bibliografii, bibliografia specjalna, bibliografia dziedzin i zagadnień, bibliografia regionalna, bibliografia osobowa, statystyka bibliografii

Bibliografia spisów bibliograficznych (bibliografia bibliografii) jest bibliografią specjalna, która dokumentuje kulturę bibliograficzną kraju i jest źródłem informacji o źródłach informacji. Jak pisała wybitna znawczyni bibliografii Helena Hleb-Koszańska, to zadanie „predestynuje ją - jak twierdzi większość bibliografów - do pełnienia funkcji jednego z członów w systemie bibliografii narodowej"1. Dlatego nie dziwi, że kraje o bogatej tradycji bibliograficznej (np. Niemcy, Czechy, Włochy) tworzą bibliografie spisów bibliograficznych, jeśli nie bieżące, to retrospektywne. Dodajmy, że istnieja też międzynarodowe bibliografie bibliografii. Do najbardziej znanych należą: Bibliotheca bibliographica Juliusa Petzholdta (wyd. 1. Leipzig 1866) zawierająca 5,5 tys. bibliografii oraz A world bibliography of bibliographies and of bibliographical catalogues, calendars, abstracts, digests, indexes and the like Theodora Bestermana (wyd. 1. London 1939-1940). Wydanie 4. tego dzieła (Lausanne 1965-1966) zawiera ponad 90 tys. bibliografii samoistnych.

Bibliografie bibliografii są też podstawą do prowadzenia wszechstronnych analiz dotyczących rozwoju bibliografii, w tym także analiz statystycznych. W piśmiennictwie polskim opracowanie tego typu bibliografii w bardzo szerokim ujęciu (światowym, krajowym, metodycznym, historycznym, także statystycznym) dał Henryk Sawoniak w publikacji Rozwój i metodyka powszechnych i narodowych bibliografii bibliografii (1971)2.

Przedmiotem zainteresowania bibliografii bibliografii są wszelkie spisy bibliograficzne - ogólne i specjalne, wydzielane ze względu na cechy związane z zakresem tematycznym (uniwersalny lub ograniczony) lub cechami dokumentów (geograficznymi, językowymi, wydawniczo-formalnymi, autorskimi, chronologicznymi). Liczba opracowywanych w kraju bibliografii świadczy o stopniu

${ }^{1}$ H. Hleb-Koszańska: O bibliografii dla niewtajemniczonych. Wrocław 1974, s. 77-78.

${ }^{2}$ H. Sawoniak: Rozwój i metodyka powszechnych i narodowych bibliografii bibliografii. Warszawa 1971. 
uporządkowania piśmiennictwa, a same bibliografie należą do podstawowych źródeł informacji bieżącej i retrospektywnej (historycznej, kulturowej). Liczba spisów bibliograficznych rośnie wraz z powiększaniem się produkcji wydawniczej, a im wyższa jest produkcja wydawnicza kraju, tym bardziej niezbędne sa opracowania bibliograficzne (obecnie często bibliograficzne bazy danych), które rejestrują i porządkuja w różny sposób ukazujące się piśmiennictwo. W ramach kraju rolę tę pełni bibliografia narodowa. Bibliografie pozwalaja przede wszystkim szybko dotrzeć do poszukiwanych zagadnień (bibliografie dziedzin i zagadnień, bibliografie regionalne). Stanowią też materiał pozwalający ocenić wysokość i różnorodność produkcji wydawniczej (bibliografie narodowe), ocenić aktywność osób i środowisk, np. naukowych (bibliografie osób i instytucji), zainteresowanie danym narodem czy krajem za granica (bibliografie eksteriorików), są też źródłem oceny rozwoju dyscyplin i kierunków (bibliografie dziedzin i zagadnień).

Według obliczeń Henryka Sawoniaka przeprowadzonych w połowie lat sześćdziesiatych XX w. na podstawie Bibliografii bibliografij polskich Wiktora Hahna od początku (tj. 1625 r. - data wydania pierwszej bibliografii autorstwa Szymona Starowolskiego) do 1950 r. opracowano w Polsce około 5500 spisów bibliograficznych, w dziesięcioleciu 1951-1960 - około 4000, a w okresie 1961-1965 - około $2500^{3}$. Liczby te wskazuja na wielki przyrost spisów bibliograficznych w okresie powojennym. W wydanej kilka lat później ksiażce O bibliografii dla niewtajemniczonych Helena Hleb-Koszańska (korzystając z obliczeń Sawoniaka) ustaliła liczbę spisów bibliograficznych (z pominięciem katalogów księgarskich i wydawniczych oraz bibliografii załącznikowych) dla okresu 1945-1960 - na około 6700 bibliografii (średnio rocznie 447), dla okresu 1961-1965 - około 2500 (średnio rocznie 500)4. Dokładne obliczenia dla późniejszego okresu nie były wykonywane, jednak można tu przyjać za podstawę skomasowane i poddane pewnej selekcji bibliografie bibliografii opracowywane w Instytucie Bibliograficznym Biblioteki Narodowej. I tak, trzecie wydanie Bibliografii bibliografij polskich do 1950 r. W. Hahna, uzupełnione przez H. Sawoniaka rejestruje 7500 pozycji, co daje średnio 23 spisy rocznie. W Bibliografii polskich 1951-1960 zamieszczono 5600 pozycji, co daje średnio rocznie 560 bibliografii. Bibliografia bibliografii polskich 1961-1970 notuje 9691 bibliografii (średnio rocznie 969), natomiast Bibliografia bibliografii polskich 19711985 notuje już 15 923, czyli średnio rocznie 1061 spisów bibliograficznych.

Do oceny stanu bibliografii nie wystarczą same dane liczbowe, ważne sa kryteria doboru i selekcji materiałów (o których dalej), a także struktura typów spisów bibliograficznych. Analizując pod tym względem Bibliografię bibliografii polskich 1961-1970, która rejestruje 9691 spisów, otrzymamy następujący rozkład typów bibliografii: bibliografie bibliografii - $12(0,12 \%)$, bibliografie ogólne - 264 (2,72\%), bibliografie dziedzin i zagadnień - 5630 (58,09\%), bibliografie regionalne - $774(7,98 \%)$, bibliografie osobowe - 2485 (25,64\%), bibliografie zawartości czasopism - 320 (3,30\%), katalogi księgarskie i wydawnicze - 206 $(2,12 \%)$.

${ }^{3}$ Ibidem, s. 317; H. Hleb-Koszańska: Aktualny stan bibliografii w Polsce oraz postulaty na przyszłość. W: Druga Ogólnokrajowa Narada Bibliografów. Warszawa 1967, s. 10.

${ }^{4}$ H. Hleb-Koszańska: O bibliografii..., op. cit., s. 214. 
Podobny rozkład procentowy otrzymamy dla Bibliografii bibliografii polskich 1971-1985, która rejestruje 15923 spisy bibliograficzne, w tym: bibliografie bibliografii - $22(0,14 \%)$, bibliografie ogólne - $162(1,01 \%)$, bibliografie dziedzin i zagadnień - $9021(56,6 \%)$, bibliografie regionalne - 1587 (9,96\%), bibliografie osobowe - 4569 (28,62\%), bibliografie zawartości czasopism - 423 (2,65\%), katalogi księgarskie i wydawnicze - $135(0,85 \%)$.

Tak więc można uznać, że dla 25-letniego okresu (1961-1985) ponad połowa (57-58\%) spisów bibliograficznych dotyczy poszczególnych dziedzin i zagadnień, $26-29 \%$ stanowią bibliografie osobowe oraz 8-10\% - bibliografie regionalne. Pozostałe typy spisów bibliograficznych są zdecydowanie mniej liczne i stanowią 5-9\% całości.

Nieco inne, choć zbliżone wskaźniki uzyskamy dla przykładowego rocznika 2005, w którym zarejestrowano 4876 bibliografii, w tym: bibliografie bibliografii - $1(0,02 \%)$, bibliografie ogólne - $29(0,59 \%)$, bibliografie dziedzin i zagadnień - $2977(61,05 \%)$, bibliografie regionalne - 661 (13,55\%), bibliografie osobowe - 1285 (26,35\%), bibliografie zawartości czasopism - $56(1,14 \%)$, katalogi księgarskie i wydawnicze - 67 (1,37\%). Warto zwrócić uwagę na bibliografie regionalne, których udział jest o jedna trzecia wyższy od okresu $1971-1985(9,96 \% ; 13,55 \%)$, bibliografie osobowe zachowuja prawie jednakowy stan $(28,62 \% ; 26,35 \%)$, podobnie bibliografie dziedzin i zagadnień $(56,6 \%$; $61,05 \%)$. Te niewielkie różnice moga być skutkiem pewnego stopnia selekcji w bibliografiach skomasowanych, zwłaszcza wśród bibliografii załącznikowych. Drugim powodem może być to, że w bibliografii obejmującej materiał za wiele lat część tytułów wychodzących jako wydawnictwa ciąłe jest komasowana do jednej pozycji, podczas gdy w rocznikach za każdym razem jest to odrębna pozycja. W tym sensie bibliografie skomasowane retrospektywne są bardziej wiarygodnym źródłem dla dłuższych okresów niż bieżące roczniki, które odzwierciedlają stan w danym roku.

Podstawą przedstawionych niżej obliczeń dla bibliografii dziedzin i zagadnień, bibliografii regionalnych i lokalnych oraz bibliografii osobowych była analiza roczników bieżącej „Bibliografii Bibliografii i Nauki o Książce” (okres 1945-1980) i „Bibliografii Bibliografii Polskich” (okres 1981-2008). Przyjęta górna granica zasięgu chronologicznego 2008 wynika z dostępności danych. Trzeba jednak pamiętać, że część spisów bibliograficznych ukazująca się w postaci wydawnictw ciagłych była odnotowywana w każdym roku, co ma wpływ na ogólna liczbę tytułów w całym badanym okresie (tego typu badania nie prowadzono). Ponadto należy zaznaczyć, że w rocznikach sprzed lat dziewięćdziesiątych zdarzały się pozycje oznaczone tym samym numerem i rozróżnione literą (a lub b). Były to pozycje, które wstawiono na etapie korekty. We wcześniejszych rocznikach swój numer kolejny otrzymywały także pozycje odsyłaczowe, podawane w nawiasie okragłym. I jedne, i drugie stanowią niewielki procent ogólnej liczby bibliografii danego typu, niemniej jednak powodują niewielkie (ok. 3-procentowe) zniekształcenie danych rzeczywistych ${ }^{5}$. Wreszcie, w kilku rocznikach dane były

${ }^{5}$ Dokładna analiza przeprowadzona przez H. Sawoniaka dla Bibliografii bibliografii polskich 1951-1960 wskazuje, że różnica między numeracją w bibliografii (5795) a liczbą rzeczywistych bibliografii (5600) wynosi 195 pozycji, co stanowi 3,36\%. Zob. H. Sawoniak: Rozwój i metodyka..., op. cit., s. 301, przypis 89. 
skomasowane i wydawane łącznie za dwa lata (1945-1946, 1950-1951, 19521953, 1964-1965) - w tych przypadkach wzięto średnią za rok. Przytoczone dane są więc obarczone pewnym błędem, mimo to daja jednak wyobrażenie o stanie i tendencjach rozwojowych bibliografii specjalnych.

W analizie uwzględniono następujące działy „Bibliografii Bibliografii Polskich” (według terminologii z ostatniego okresu): III. Bibliografie dziedzin i zagadnień oraz typów dokumentów, IV. Bibliografie krajoznawcze, terytorialne oraz grup etnicznych, V. Bibliografie osobowe. Pominięto bibliografie specjalne z działów: VI. Bibliografie zawartości poszczególnych czasopism, VII. Katalogi księgarskie i wydawnicze.

Celem analizy była odpowiedź na pytania o to, jak rozwijały się główne typy bibliografii specjalnych (dziedzin i zagadnień, regionalne i lokalne, osobowe) w całym badanym okresie, jaka była dynamika ich rozwoju w poszczególnych dekadach, jakie czynniki mogły mieć znaczenie dla tego rozwoju.

\section{Bieżąca bibliografia bibliografii}

Powojenne prace nad polską bibliografią bibliografii wiażą się z działalnością powołanego w 1946 r. Państwowego Instytutu Książki w Łodzi ${ }^{6}$. Jednym z jego zadań była dokumentacja ukazujących się w Polsce spisów bibliograficznych i piśmiennictwa z zakresu nauki o książce oraz publikowanie wyników w formie bibliografii. Od 1947 r. PIK wydawał publikację pt. „Bibliografia Bibliografii i Nauki o Książce” (BBiNoK), która z kolei była kontynuacja „Bibliografii Bibliofilstwa i Bibliografii Polskiej”, ukazującej się w latach 1914-1922 oraz „Bibliografii Bibliografii, Bibliotekarstwa i Bibliofilstwa”, która wychodziła w latach 1928 i 1930-1936 jako dodatek do „Przeglądu Bibliotecznego”. Po likwidacji PIK we wrześniu 1949 r. i przejęciu zadań dokumentacyjno-bibliograficznych przez Instytut Bibliograficzny Biblioteki Narodowej, od czwartego kwartału 1949 r. bieżące roczniki „Bibliografii Bibliografii i Nauki o Książce” były przygotowywane w Instytucie Bibliograficznym (w Dziale Teorii Bibliografii, przekształconym później w Zakład Teorii i Organizacji Bibliografii). Niestety, bibliografia ukazywała się z opóźnieniami, na co zwracała uwagę Helena Hleb-Koszańska podczas pierwszej Ogólnokrajowej Narady Bibliografów (1956) - na przykład bibliografia za lata 1945-1946 ukazała się dopiero w roku 1955. Również w latach następnych bibliografia ta miała, dochodzące nawet do 10 lat, opóźnienia i dopiero od połowy lat dziewięćdziesiątych sytuacja poprawiła się, co było wynikiem radykalnych zmian na rynku poligraficznym. Od 1995 r. ukazuje się w dwa i pół roku w stosunku do roku wydania zebranych materiałów (ostatni dostępny rocznik obejmuje materiał z 2008 r.).

Pierwotnie „Bibliografia Bibliografii i Nauki o Książce” rejestrowała we wspólnym układzie zarówno spisy bibliograficzne, jak i piśmiennictwo bibliologiczne. Od rocznika 1968 BBiNoK podzielono na dwie części: cz. 1: „Bibliografia Bibliografii Polskich” (spisy) i cz. 2: „Polska Bibliografia Bibliologiczna” (piśmiennictwo

${ }^{6} \mathrm{O}$ działalności bibliograficznej PIK zob. M. Korczyńska-Derkacz: Państwowy Instytut Książki (1946-1949) i jego rola w rozwoju bibliologii, bibliotekarstwa i kultury książki w Polsce. Wrocław 2011. 
dziedziny). W rocznikach 1969-1980 każda z części ukazywała się oddzielnie, jednak z zachowaniem wspólnego tytułu. Od rocznika 1981 obie bibliografie przekształcono w samodzielne publikacje (roczniki), ukazujące się pod własnymi tytułami. Praktycznie od 1969 r. bibliografia ta ma jednolitą strukturę, co jest ważne z badawczego punktu widzenia.

W bieżącym roczniku „Bibliografii Bibliografii Polskich” rejestrowane sa zarówno spisy bibliograficzne, jak i specjalne formy bibliografii, tj. przeglądy bibliograficzne oraz omówienia stanu badań za dany rok. Rejestrowane sa bibliografie ogólne i specjalne: dziedzin i zagadnień, regionalne i lokalne, osobowe, zawartości poszczególnych czasopism, opublikowane centralne katalogi ogólne i specjalne, opublikowane katalogi zbiorów bibliotecznych (ogólnych i specjalnych). Pod względem zasięgu wydawniczego rejestruje: wydawnictwa samoistne (zwarte i ciagłe), artykuły oraz fragmenty bibliograficzne $w$ formie drukowanej i elektronicznej (CD-ROM, online). Uwzględniane są bibliografie wszystkich typów dokumentów: piśmiennictwa drukowanego, rękopisów, starych druków, archiwaliów, nut, map, rycin, plakatów, przepisów i aktów prawnych i normatywnych, norm, patentów, mikrofilmów i nagrań dźwiękowych, dysertacji oraz baz danych bibliograficznych, bibliografie dokumentów audiowizualnych (płyt, nagrań na taśmach magnetycznych, filmów, mikrofilmów, przezroczy). Pod względem zasięgu terytorialnego i językowego rejestruje publikacje krajowe i polonika zagraniczne.

Selekcji podlegaja spisy bibliograficzne, których wartość informacyjna dla użytkownika i wartość dokumentalna dla historii bibliografii jest niewielka. Są to: bibliografie załącznikowe przy artykułach (z wyjątkiem bibliografii osobowych i regionalnych), przy drukach zwartych, gdy liczą mniej niż 150 pozycji (z wyjatkiem bibliografii osobowych i regionalnych), przy bibliografiach. regionalnych i osobowych poniżej 30 pozycji, z wyjatkiem bibliografii osób, których działalność lub piśmiennictwo przypadło na okres do XIX w. włącznie. Ponadto nie są rejestrowane niewielkie tematyczne zestawienia bibliograficzne, katalogi wydawnicze publikowane jako czasopisma, księgarskie i wydawnicze druki reklamowe, wykazy lektur, spisy treści czasopism, tzw. ekspres-informacje, przeglądy dokumentacyjne wydawane przez ośrodki zakładowe inte ${ }^{7}$.

\section{Bibliografie dziedzin i zagadnień}

Bibliografie dziedzin i zagadnień powstawały (powstaja) głównie w trzech grupach instytucji: placówkach (instytuty, zakłady, ośrodki) Polskiej Akademii Nauk, naukowych bibliotekach specjalnych (Główna Biblioteka Lekarska, Centralna Biblioteka Wojskowa, Centralna Biblioteka Rolnicza, Centralna Biblioteka Statystyczna, Główna Biblioteka Pracy i Zabezpieczenia Społecznego, Biblioteka Narodowa), instytutach naukowych resortowych i podległych urzędom centralnym (np. Instytut Badań Leśnictwa, Instytut Morski). Oczywiście bibliografie dziedzin i zagadnień mogą także powstawać w bibliotekach i innych ośrodkach czy organizacjach (towarzystwach) naukowych.

${ }^{7}$ M. Przybysz: Polska bieżąca bibliografia bibliografii i nauki o książce. „Zagadnienia Informacji Naukowej" 2002, nr 2, s. 76-85. 
Bibliografie te ukazują się jako publikacje samoistne (książki, czasopisma), ale wielką ich część stanowią bibliografie załącznikowe zamieszczane przy publikacjach naukowych. Dlatego można uznać, że jeśli wzrasta produkcja wydawnicza dzieł (zwłaszcza naukowych), to wzrasta również liczba bibliografii dziedzin i zagadnień. Ten typ bibliografii dotyczy różnorodnych tematów o różnych zakresach, np. w Bibliografii bibliografii polskich 1961-1970 uwzględniono 279 tematów, a w 1971-1985 - 271. Dla porównania, w roczniku „Bibliografii Bibliografii Polskich" za 2005 rok jest 220 tematów. Można więc uznać, że bibliografie dziedzin i zagadnień dotyczą około 300 tematów (klas) zróżnicowanych zakresowo. Są to przede wszystkim tematy-nazwy dziedzin, dyscyplin, kierunków, np.: Administracja, Akustyka, Anatomia, Anestezjologia, Antropologia, Archeologia, Botanika, Chirurgia, Dermatologia, Endokrynologia, ale także pojedynczych przedmiotów, jak np. Alkoholizm, Drzewa, Góry, Korozja, Młodzież, Nafta, Niewidomi, Opakowania, Torf itp. Są też tematy formalne typu: Dysertacje, Encyklopedie, Normy, Nuty, Płyty, Wydawnictwa urzędowe. Analiza spisów bibliograficznych za lata 1979-1993 przeprowadzona przez Teresę Pawlikowa ${ }^{8}$ wykazała, że najliczniej reprezentowane są dyscypliny humanistyczne: bibliologia, historia, językoznawstwo, literatura, prawo, naukoznawstwo, pedagogika, religioznawstwo. Wielkość opublikowanych bibliografii dziedzin i zagadnień w ciagu ponad 60 lat ilustrują tabele 1 i 2.

Tabela 1

Liczba bibliografii dziedzin i zagadnień w latach 1945-2008

\begin{tabular}{|c|c|c|c|c|c|c|c|}
\hline Lata & $1945-1950$ & $1951-1960$ & $1961-1970$ & $1971-1980$ & $1981-1990$ & $1991-2000$ & 2001-2008 \\
\hline Ogółem & 1002 & 5821 & 8516 & 13119 & 12098 & 13321 & 20356 \\
\hline
\end{tabular}

Średnia roczna bibliografii dziedzin i zagadnień w latach 1945-2008

Tabela 2

\begin{tabular}{|c|c|c|c|c|c|c|c|}
\hline Lata & $1945-1950$ & $1951-1960$ & $1961-1970$ & $1971-1980$ & $1981-1990$ & $1991-2000$ & 2001-2008 \\
\hline $\begin{array}{c}\text { Średnia } \\
\text { roczna }\end{array}$ & 167 & 582,1 & 851,6 & 1311,9 & 1209,8 & 1332,1 & 2544,5 \\
\hline
\end{tabular}

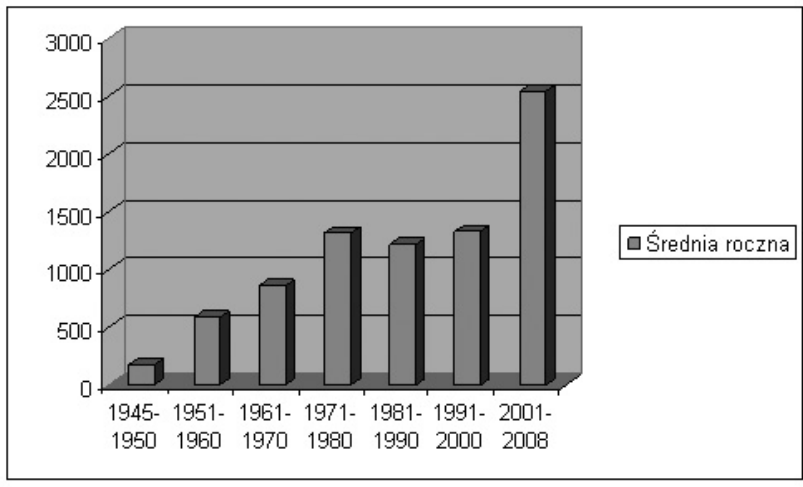

Wykres do tabeli 2

${ }^{8}$ T. Pawlik: Stan bibliografii dziedzin i zagadnień w latach 1979-1993. W: Czwarta Ogólnokrajowa Narada Bibliografów. Warszawa 1996, s. 160-167. 
Analiza statystyczna wskazuje, że w latach siedemdziesiąych, osiemdziesiątych i dziewięćdziesiątych bibliografie dziedzin i zagadnień utrzymywały się na wysokim, ale prawie jednakowym poziomie (12-13 tys. w dekadzie, średnio rocznie $1200-1300$ pozycji), intensywny wzrost nastapił od roku 2000 , gdy średnia roczna przekroczyła 2500 bibliografii. Wydaje się, że jest to skutek nie tylko zwiększonej produkcji wydawniczej - zwiększyła się ona zdecydowanie od połowy lat dziewięćdziesiątych, ale także skutek rozbudowanych bibliografii załącznikowych, będących z kolei wynikiem łatwości w dostępie do publikacji znajdowanych w bazach danych. Dlatego wydaje się uzasadnione zrewidowanie zasad doboru i selekcji bibliografii załącznikowych do „Bibliografii Bibliografii Polskich".

\section{Bibliografie regionalne i lokalne}

W grupie bibliografii regionalnych i lokalnych, zwanych też terytorialnymi, znajdują się bibliografie obejmujące swym zasięgiem obszar kraju lub kontynentu (bibliografie krajoznawcze), bibliografie obejmujące duże obszary wewnątrz kraju (bibliografie regionalne) oraz bibliografie odnoszące się do miejscowości lub miejsca toponimicznego (Dolina Biebrzy, Puszcza Białowieska) i grupy etnicznej niepowiazanej wyraźnie z żadnym terytorium (np. Arabowie, Cyganie, Żydzi). Bibliografie te maja głównie charakter przedmiotowy, tj. dotyczą danego regionu, miejscowości. Zdecydowana większość to bibliografie lokalne. Jak powiedziano wcześniej, stanowią one stosunkowo niewielki odsetek wszystkich bibliografii (ok. 10-12\%), jednakże wskaźnik dynamiki ich rozwoju jest najwyższy. W ciagu 60 lat ich liczba wzrosła ponad 40-krotnie, przy czym w każdej dekadzie podwajała się, z wyjatkiem pewnej stabilności na średnim poziomie 145-150 bibliografii rocznie w latach siedemdziesiątych i osiemdziesiątych. W latach dziewięćdziesiątych średnia roczna ponownie podwoiła się i wynosiła 293,4 bibliografie, kolejne podwojenie nastapiło w ostatniej dekadzie (zob. tab. 3). Należałoby to chyba wiązać nie tylko ze wzrostem produkcji wydawniczej, ale także z działalnością ośrodków i towarzystw lokalnych, które od czasu reformy samorządowej w 1991 r. wykazują coraz większą aktywność. Jest to widoczne również na polu prasy regionalnej.

Tabela 3

Liczba bibliografii regionalnych, lokalnych i krajoznawczych w latach 1945-2008

\begin{tabular}{|c|c|c|c|c|c|c|c|}
\hline Lata & $1945-1950$ & $1951-1960$ & $1961-1970$ & $1971-1980$ & $1981-1990$ & $1991-2000$ & 2001-2008 \\
\hline Ogółem & 113 & 446 & 1079 & 1455 & 1512 & 2934 & 4684 \\
\hline
\end{tabular}

Tabela 4 Średnia roczna bibliografii regionalnych, lokalnych i krajoznawczych w latach 1945-2008

\begin{tabular}{|c|c|c|c|c|c|c|c|}
\hline Lata & $\mathbf{1 9 4 5 - 1 9 5 0}$ & $\mathbf{1 9 5 1 - 1 9 6 0}$ & $\mathbf{1 9 6 1 - 1 9 7 0}$ & $\mathbf{1 9 7 1 - 1 9 8 0}$ & $\mathbf{1 9 8 1 - 1 9 9 0}$ & $\mathbf{1 9 9 1 - 2 0 0 0}$ & $\mathbf{2 0 0 1 - 2 0 0 8}$ \\
\hline $\begin{array}{c}\text { Średnia } \\
\text { roczna }\end{array}$ & 18,8 & 44,6 & 107,9 & 145,5 & 151,2 & 293,4 & 585,5 \\
\hline
\end{tabular}




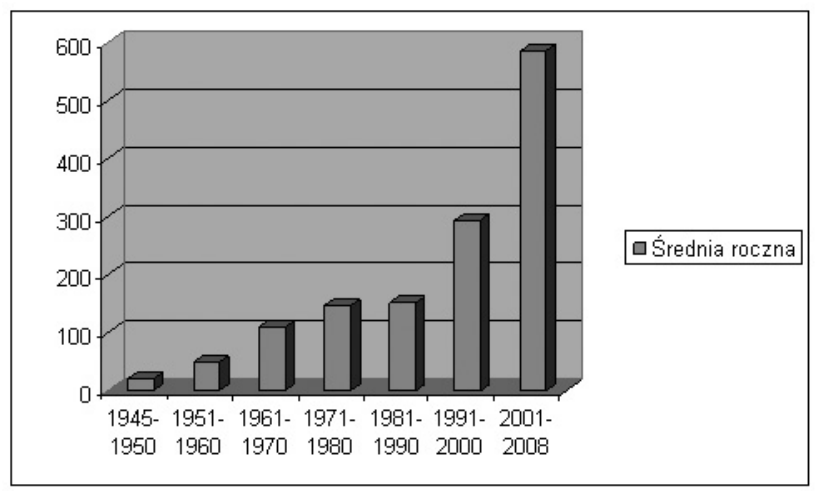

Wykres do tabeli 4

\section{Bibliografie osobowe}

Bibliografie osobowe dzielone są na dwie grupy: bibliografie poszczególnych osób i zespołów osobowych oraz bibliografie instytucji (organizacji), przy czym mogą one mieć charakter podmiotowy (piśmiennictwo osób indywidualnych i zespołów) lub przedmiotowy (piśmiennictwo o osobach/instytucjach/ organizacjach) lub podmiotowo-przedmiotowy. Sa one stosunkowo licznie reprezentowane i wykazują stały przyrost. Dominują bibliografie podmiotowe, co jest zrozumiałe, bowiem o wielu osobach brak jest jakichkolwiek materiałów. Porównanie średnich rocznych z poszczególnych dekad (tab. 6) wskazuje na rosnace zainteresowanie tym typem bibliografii, zwłaszcza od końca lat osiemdziesiątych, gdy rocznie pojawiało się około 500 bibliografii osobowych. W ciagu ostatniej dekady liczba bibliografii osobowych zbliżyła się i przekroczyła 1000. Można przypuszczać, że jest to z jednej strony skutek wzrostu produkcji wydawniczej, podobnie jak przy bibliografii dziedzin i zagadnień, z drugiej zaś strony wydaje się, że w ostatnim trzydziestoleciu wzrosło zainteresowanie materiałami biograficznymi (pamiętniki, wspomnienia, autobiografie), na co zapewne miały też wpływ zmiany społeczno-ustrojowe od roku 1990, w tym zniesienie cenzury. Z badań Artura Znajomskiego (okres 1989-2000) ${ }^{9}$ wynika, że bibliografie dotyczą najczęściej uczonych wszystkich kierunków i dyscyplin naukowych. Najliczniej reprezentowani sa przedstawiciele nauk humanistycznych i społecznych, znacznie mniej jest przedstawicieli nauk przyrodniczych, jeszcze mniej nauk matematycznych i technicznych. Kolejna duża grupa to pisarze i publicyści. Zauważalny jest przyrost bibliografii artystów (muzyków, piosenkarzy, reżyserów, aktorów), świętych i błogosławionych, polityków, dostojników kościelnych. Warto tu podkreślić, że w okresie 1989-2000 opracowano aż 96 bibliografii papieża Jana Pawła II.

Jeśli chodzi o bibliografie instytucji, to najliczniej reprezentowane są szkoły wyższe. Jest to zrozumiałe, bowiem dorobek bibliograficzny uczelni jest świa-

${ }^{9}$ A. Znajomski: Bibliografie specjalne - tendencje rozwoju na przykładzie bibliografii osobowych. W: Piąta Ogólnokrajowa Narada Bibliografów Warszawa 11-13 czerwca 2003. Warszawa 2004, s. 213-228. 
dectwem jej rangi (czasem tylko formalnej). Często też swoje bibliografie opracowują wydziały i instytuty uczelniane, jak również inne ośrodki naukowe, m.in. PAN. Bibliografie te obecnie często dostępne są na stronach domowych uczelni lub bibliotek uczelnianych. Niezbyt często spotyka się bibliografie archiwów, muzeów, bibliotek oraz towarzystw naukowych. Zazwyczaj są to bibliografie podmiotowe, choć niektóre uczelnie mają także bibliografie przedmiotowe ${ }^{10}$.

W Bibliografii bibliografii polskich 1961-1970 zarejestrowano 2485 bibliografii osobowych, w tym 645 bibliografii zespołów osobowych (instytucji) oraz 1840 bibliografii osób. Na tej podstawie można szacować, że bibliografie zespołów osobowych stanowią około $26 \%$ tego typu bibliografii, a bibliografie osób $74 \%$.

Tabela 5

Liczba bibliografii osobowych w latach 1945-2008

\begin{tabular}{|c|c|c|c|c|c|c|c|}
\hline Lata & $1945-1950$ & $1951-1960$ & $1961-1970$ & $1971-1980$ & $1981-1990$ & $1991-2000$ & 2001-2008 \\
\hline Ogółem & 435 & 1876 & 3345 & 4035 & 4504 & 6858 & 8828 \\
\hline
\end{tabular}

Średnia roczna liczba bibliografii osobowych w latach 1945-2008

Tabela 6

\begin{tabular}{|c|c|c|c|c|c|c|c|}
\hline Lata & $\mathbf{1 9 4 5 - 1 9 5 0}$ & $\mathbf{1 9 5 1 - 1 9 6 0}$ & $\mathbf{1 9 6 1 - 1 9 7 0}$ & $\mathbf{1 9 7 1 - 1 9 8 0}$ & $\mathbf{1 9 8 1 - 1 9 9 0}$ & $\mathbf{1 9 9 1 - 2 0 0 0}$ & $\mathbf{2 0 0 1 - 2 0 0 8}$ \\
\hline $\begin{array}{c}\text { Średnia } \\
\text { roczna }\end{array}$ & 72,5 & 187,6 & 334,5 & 403,5 & 450,4 & 685,8 & 1103,5 \\
\hline
\end{tabular}

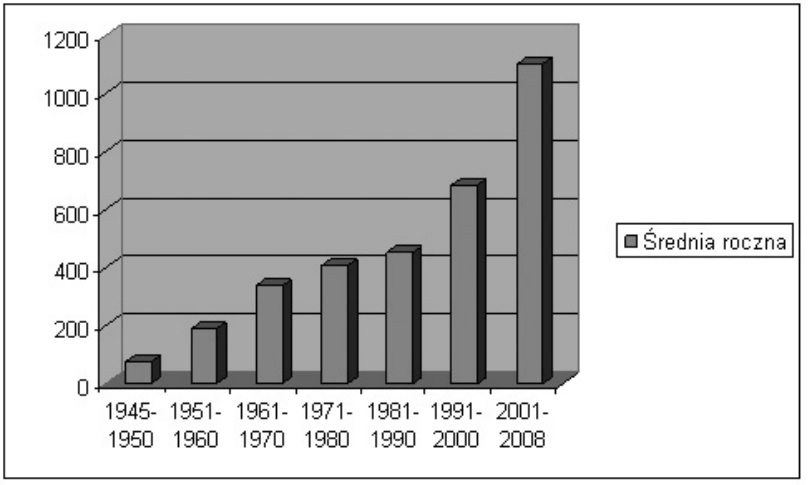

Wykres do tabeli 6

\section{Podsumowanie}

Ogólnie należy uznać, że bibliografie specjalne rozwijały się dobrze, wykazując w zasadzie stałą dynamikę wzrostowa. Dotyczy to zwłaszcza bibliografii osobowych w całym okresie (zob. wykres do tab. 6) oraz bibliografii regionalnych i lokalnych w ostatnim dwudziestoleciu (zob. wykres do tab. 4). Trzeba oczywiście wziać pod uwagę odmienność sytuacji w okresie bezpośrednio po wojnie, gdy instytucje nauki i kultury, w tym uczelnie, biblioteki i wydawnictwa

${ }^{10}$ A. Znajomski: Bibliografie zespołów osobowych - instytucji. Stan i potrzeby. W: Bibliografia. Teoria, praktyka, dydaktyka. Warszawa 2009, s. 117-129. 
odradzały się po zniszczeniach wojennych i sytuacji po roku 1990, po transformacji społeczno-ustrojowej, której efektem był m.in. wolny rynek wydawniczy i poligraficzny. Niemniej jednak już nawet w latach 1945-1946 w „Bibliografii Bibliografii i Nauki o Książce" zarejestrowano 81 bibliografii dziedzin i zagadnień, 13 bibliografii regionalnych oraz 62 bibliografie osobowe. W następnych dekadach liczby te wzrastały.

Jeśli natomiast chodzi o dynamikę rozwoju, to najintensywniej rozwijały się bibliografie regionalne i lokalne, które w stosunku do okresu 1945-1950 wzrosły 41-krotnie, natomiast bibliografie dziedzin i zagadnień oraz bibliografie osobowe wzrosły 20-krotnie. Rozwój ilościowy oraz dynamikę rozwoju bibliografii w poszczególnych okresach ilustruje tabela 7.

Tabela 7

Liczba bibliografii oraz dynamika rozwoju bibliografii dziedzin i zagadnień, regionalnych i lokalnych oraz osobowych w latach 1945-2008

\begin{tabular}{|c|c|c|c|c|c|c|}
\hline \multirow{2}{*}{ Lata } & \multicolumn{2}{|c|}{$\begin{array}{c}\text { Bibliografie dziedzin } \\
\text { i zagadnień }\end{array}$} & \multicolumn{2}{c|}{$\begin{array}{c}\text { Bibliografie regionalne } \\
\text { i lokalne }\end{array}$} & \multicolumn{2}{c|}{$\begin{array}{c}\text { Bibliografie } \\
\text { osobowe }\end{array}$} \\
\cline { 2 - 7 } & $\begin{array}{c}\text { Liczba } \\
\text { pozycji }\end{array}$ & $\begin{array}{c}\text { wskaźnik } \\
\%\end{array}$ & $\begin{array}{c}\text { Liczba } \\
\text { pozycji }\end{array}$ & $\begin{array}{c}\text { wskaźnik } \\
\%\end{array}$ & $\begin{array}{c}\text { Liczba } \\
\text { pozycji }\end{array}$ & $\begin{array}{c}\text { wskaźnik } \\
\%\end{array}$ \\
\hline $\begin{array}{c}1945- \\
1950\end{array}$ & 1002 & 100,00 & 113 & 100,00 & 435 & 100,00 \\
\hline $\begin{array}{c}1951- \\
1960\end{array}$ & 5821 & 580,93 & 446 & 394,69 & 1876 & 431,26 \\
\hline $\begin{array}{c}1961- \\
1970\end{array}$ & 8516 & 849,90 & 1079 & 954,86 & 3345 & 768,96 \\
\hline $\begin{array}{c}1971- \\
1980\end{array}$ & 13119 & 1309,28 & 1455 & 1287,61 & 4035 & 927,58 \\
\hline $\begin{array}{c}1981- \\
1990\end{array}$ & 12098 & 1207,38 & 1512 & 1338,05 & 4504 & 1035,40 \\
\hline $\begin{array}{c}1991- \\
2000\end{array}$ & 13321 & 1329,44 & 2934 & 2596,46 & 6858 & 1576,55 \\
\hline $\begin{array}{c}2001- \\
2008\end{array}$ & 20356 & 2031,54 & 4684 & 4145,13 & 8828 & 2029,42 \\
\hline
\end{tabular}

Analiza ilościowa może być punktem wyjścia do pogłębionych badań naukoznawczych, regionalnych, historycznych, kulturowych. Liczba opracowywanych w kraju spisów bibliograficznych nie jest tylko wykazem statystycznym, ale także podstawą oceny różnych aspektów życia narodu. Helena Hleb-Koszańska, analizując dane dotyczące rozwoju ilościowego bibliografii w Polsce do roku 1960, napisała: „Przyjrzawszy się temu zestawieniu bezbłędnie się rozpozna współzależność między wzrostem liczby bibliografii a rozwojem nauki, kultury i piśmiennictwa oraz życiem politycznym kraju"11.

${ }^{11}$ H. Hleb-Koszańska: O bibliografii..., op. cit., s. 79. 


\section{Źródła}

\section{Bieżące bibliografie bibliografii}

„Bibliografia Bibliografii i Nauki o Książce” (roczniki 1945-1980).

„Bibliografia Bibliografii Polskich” (roczniki 1981-2008).

\section{Retrospektywne bibliografie bibliografii (układ chronologiczny)}

Hahn Wiktor: Bibliografia bibliografij polskich: do roku 1950. Wyd. 2 uzup. Wrocław: Zakł. Nar. im. Ossolińskich - Wydawnictwo, 1956.

Hahn Wiktor: Bibliografia bibliografij polskich: do roku 1950. Wyd. 3 uzup. Henryk Sawoniak. Wrocław: Zakł. Nar. im. Ossolińskich - Wydawnictwo, 1966.

Sawoniak Henryk: Bibliografia bibliografii polskich: 1951-1960. Wrocław: Zakł. Nar. im. Ossolińskich, 1967.

Bieńkowa Maria Barbara, Eychlerowa Barbara: Bibliografia bibliografii polskich 1961-1970. Warszawa: Biblioteka Narodowa, 1992.

Pawlikowa Teresa, Przybysz Marzena: Bibliografia bibliografii polskich 19711985. Warszawa: Biblioteka Narodowa, 2006.

\section{Bibliografia}

1. Hleb-Koszańska H.: Aktualny stan bibliografii w Polsce oraz postulaty na przyszłość. W: Druga Ogólnokrajowa Narada Bibliografów, Warszawa 20 VI 1966: referaty i dyskusja. Warszawa 1967, s. 24-33.

2. Hleb-Koszańska H.: O bibliografii dla niewtajemniczonych. Wrocław 1974.

3. Pawlik T.: Stan bibliografii dziedzin i zagadnień w latach 1979-1993. W: Czwarta Ogólnokrajowa Narada Bibliografów, Warszawa 7-9 czerwca 1995. Warszawa 1996, s. 160-167.

4. Przybysz M.: Polska bieżąca bibliografia bibliografii i nauki o książce. „Zagadnienia Informacji Naukowej" 2002, nr 2, s. 76-85.

5. Sawoniak H.: Rozwój i metodyka powszechnych i narodowych bibliografii bibliografii. Warszawa 1970.

6. Znajomski A.: Bibliografie specjalne - tendencje rozwoju na przykładzie bibliografii osobowych. W: Piąta Ogólnokrajowa Narada Bibliografów, Warszawa 11-13 czerwca 2003. Warszawa 2004, s. 213-228.

7. Znajomski A.: Bibliografie zespołów osobowych - instytucji. Stan i potrzeby. W: Bibliografia. Teoria, praktyka, dydaktyka. Praca zbiorowa pod red. Jadwigi Woźniak-Kasperek i Mikołaja Ochmańskiego. Warszawa 2009, s. 117-129.

\section{Summary}

The article presents quantitative data concerning bibliographies in Poland in the years 1945-2008, with particular attention put on domain and field bibliographies, regional and local bibliographies, and personal bibliographies. The first group is the largest (1159,9 annual average for the whole period), next is the latter (466,9 annual average), and the smallest is the group consisting of regional and local bibliographies (191,4 annual average). However, this group represents the highest dynamics of increase. The analysis was prepared basing on the "Bibliography of Bibliography and Bibliology", and the "Bibliography of Polish Bibliographies". Data are presented according to decades. 